$1-1-1935$

\title{
Copper Sulphate as an Aanthelmintic for Gastro- Intestinal Parasites of Sheep
}

\author{
J. H. Rietz
}

Follow this and additional works at: https://researchrepository.wvu.edu/ wv_agricultural_and_forestry_experiment_station_bulletins

\section{Digital Commons Citation}

Rietz, J. H., "Copper Sulphate as an Aanthelmintic for Gastro-Intestinal Parasites of Sheep" (1935). West Virginia Agricultural and Forestry Experiment Station Bulletins. 264.

https://researchrepository.wvu.edu/wv_agricultural_and_forestry_experiment_station_bulletins/265 @ WVU. It has been accepted for inclusion in West Virginia Agricultural and Forestry Experiment Station Bulletins by an authorized administrator of The Research Repository @ WVU. For more information, please contact ian.harmon@mail.wvu.edu. 
Digitized by the Internet Archive in 2010 with funding from

Lyrasis Members and Sloan Foundation 
Copper Sulphate as an Anthelmintic for Gastro-Intestinal Parasites of Sheep

By J. H. RIETZ 


\section{Copper Sulphate as an Anthelmintic for Gastro-Intestinal Parasites of Sheep}

By J. H. RIETZ

THE CONTROL of gastro-intestinal parasites has become one of the major problems confronting sheep husbandmen throughout much of the sheep-raising area of the United States.

In West Virginia the sheep ranges for the most part are permanently fenced pastures; consequently the sheep range over the same area year after year. This adds to the constant accumulation of infestation in the pastures and the likelihood of infestation in the sheep.

The object of this investigation was to find more effective methods of treatment for stomach worms and to observe the effect of the treatment upon the species of parastites infesting the intestinal tract.

In Table 1 are listed the names of the parasites encountered and identified during the investigation.

TABLE 1-Parasites found one or more times during the experiment

\begin{tabular}{ll}
\hline \hline \multicolumn{1}{c}{ Scientific name } & Popular name \\
\hline Hosmonchus contortus & Stomach worm \\
Ostertagia sp. & Stomach worm \\
Gesophagostomum columbianum & Nodular worm \\
Bunostomum trigonocephalum & Hook worm \\
Trichuris ovis & Whip worm \\
Cooperia sp. & Hair worm \\
Nematodirus sp. & Hair worm \\
Chabertia ovina & \\
Moniezia expansa & Tape worm \\
Moniezia alba & Tape worm \\
Oestrus ovis larvae & Grubs \\
Dictyocaulus filaria & Lung worm \\
Synthetocaulus rufescens & Lung worm \\
Eimeria faurei & Coccidia \\
Cysticercus tenuicollis & Tapeworm cyst \\
\hline \hline
\end{tabular}

EXPERIMENTS WITH FLOCK A

\section{Manner of treating and handling}

Thirty sheep that showed symptoms of advanced parasitism were numbered for identification and divided into two lots, I and II. The sheep in Lot I were drenched with 3 ounces of a 1 percent solution of copper sulphate; those in Lot II with 3. ounces of a $11 / 2$ percent solution of copper sulphate. Food was withheld from both lots for the 24-hour period before each treatment; it was not withheld from any of the sheep after drenching. Both lots were treated at intervals of 21 days throughout the period of the experiment, regardless of the season or feeding conditions.

Three untreated sheep were placed in the flock as controls.

\section{ACKNOWLEDGMENT}

Credit is due Dr. E. N. Moore of the West Virginia State Department of Agriculture, who assisted in carrying out the details of this work. 
The range over which these sheep grazed consisted of approximately 12 acres, cross-fenced so that the closing of two gates provided three pastures of approximately four acres each. Ordinarily the sheep had the free range of the entire pasture, but occasionally they were confined to one of the small pastures. When the grass on the range became inadequate the pasture was supplemented with hay and grain, regardless of the season. This limited range assured pastures that were heavily infested with parasite larvae and ova.

The water supply was from a small stream that flowed through the three pastures.

Lots I and II and the control sheep were pastured and fed together as one flock unit, A, from July, 1930, until the termination of the experiment and the autopsy of the sheep. The last autopsy in Lots I and II occurred respectively in April and June, 1931.

Determination of parasite ova in the feces

A count of the nematode ova was made from the fecal deposit of each sheep before treatment was begun, and again two weeks after each treatment.

The method described by Stoll (1) for counting hookworm ova was used to determine the number of ova in the feces.

All sheep in Flock A were autopsied for a count of parasites remaining in the carcass.

TABLE 2-Nematode ova count in feces of sheep in Lot I before treatment was begun and following the treatment* indicated

\begin{tabular}{|c|c|c|c|c|c|c|c|}
\hline \multicolumn{8}{|c|}{ Number of treatments } \\
\hline $\begin{array}{l}\text { Animal } \\
\text { number }\end{array}$ & 0 & 3 & 6 & 8 & 11 & 12 & 13 \\
\hline $\begin{array}{l}12 \\
39 \\
56 \\
58 \\
15 \\
33 \\
31 \\
5 \\
34 \\
35 \\
54 \\
63 \\
46 \\
65 \\
64 \\
\text { Decrease }\end{array}$ & $\begin{array}{r}600 \\
350 \\
1000 \\
12000 \\
1500 \\
1050 \\
2000 \\
100 \\
150 \\
700 \\
4500 \\
1000 \\
1500 \\
1250 \\
1250\end{array}$ & $\begin{array}{r}1100 \\
400 \\
1700 \\
5000 \\
400 \\
200 \\
50 \\
200 \\
100 \\
400 \\
1000 \\
300 \\
1500 \\
1250 \\
850 \\
50 \%\end{array}$ & $\begin{array}{c}400 \\
200 \\
150 \\
50 \\
100 \\
500 \\
100 \\
100 \\
300 \\
500 \\
400 \\
81.2 \%\end{array}$ & $\begin{array}{c}500 \\
50 \\
50 \\
200 \\
600 \\
0 \\
3000 \\
500 \\
500 \\
100 \\
55.8 \%\end{array}$ & $\begin{array}{c}50 \\
6000 \\
1000 \\
500 \\
100 \\
21.7 \%\end{array}$ & $\begin{array}{r}1000 \\
700 \\
100 \\
35 \%\end{array}$ & $\begin{array}{r}150 \\
88 \% \\
\end{array}$ \\
\hline
\end{tabular}

$*$ Fasted 24 hours
intervals of 21 days.

Res'ults of treatment

Tables 2 and 3 show the count of nematode ova in the feces of the sheep in Lot I before treatment was begun and after the third, sixth, eighth, eleventh, twelfth, and thirteenth treatment. The condition of the sheep and the manner of each species of parasite found at autopsy are also shown.

A comparison of the total ova count in the feces of sheep before treatment and after the last treatment just preceding autopsy, 


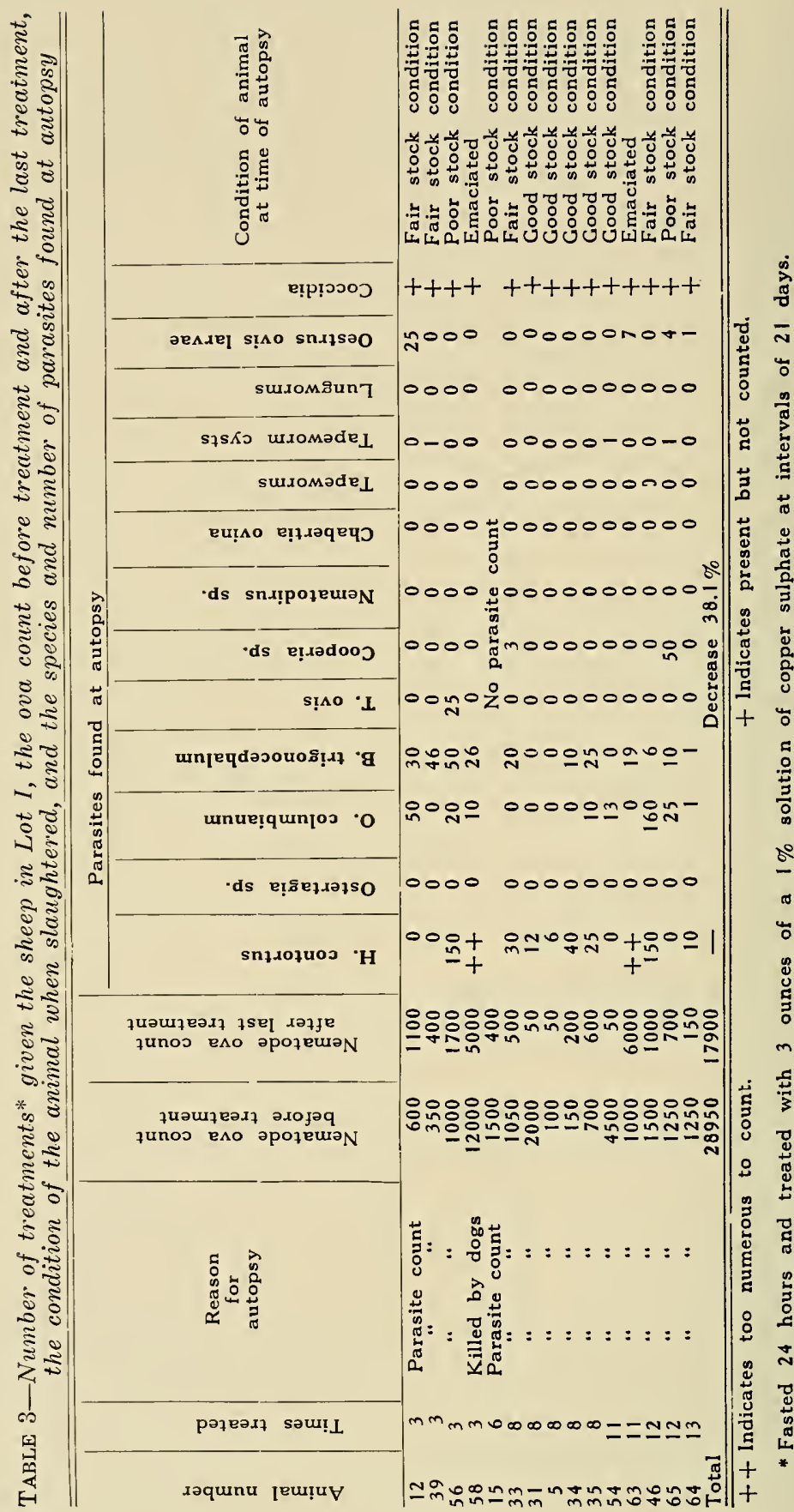


shows a reduction of 38.1 percent in nematode ova during the period of treatment. If one sheep, No. 63, (see also Table 2) is eliminated from the experiment, the reduction in ova will be 71.7 percent. This animal did not respond to treatment but showed a marked increase in ova in its feces during the period of treatment.

Tables 4 and 5 show the count of nematode ova in the feces of the sheep in Lot II before treatment was begun and after the third, sixth, eighth, eleventh, twelfth, and thirteenth treatment. The condition of the sheep and the number of each parasite found at autopsy is also shown.

TABLE 4-Nematode ova count in feces of sheep in Lot II before treatment and following the treatment* indicated

\begin{tabular}{|c|c|c|c|c|c|c|c|c|}
\hline \multicolumn{9}{|c|}{ Number of treatments } \\
\hline $\begin{array}{l}\text { Animal } \\
\text { number }\end{array}$ & 0 & 3 & 6 & 8 & 11 & 12 & 13 & 16 \\
\hline $\begin{array}{l}19 \\
29 \\
20 \\
21 \\
26 \\
6 \\
14 \\
37 \\
45 \\
60 \\
52 \\
59 \\
51 \\
53 \\
62 \\
\text { Decrease }\end{array}$ & $\begin{array}{r}650 \\
4600 \\
650 \\
200 \\
100 \\
900 \\
250 \\
1050 \\
1250 \\
3000 \\
6000 \\
900 \\
15000 \\
1250 \\
5000\end{array}$ & $\begin{array}{r}50 \\
700 \\
900 \\
0 \\
0 \\
100 \\
0 \\
0 \\
1700 \\
50 \\
7000 \\
700 \\
10000 \\
250 \\
5000 \\
35.1 \% \\
\end{array}$ & $\begin{array}{c}300 \\
50 \\
100 \\
200 \\
100 \\
100 \\
150 \\
50 \\
2500 \\
150 \\
1500 \\
200 \\
2000 \\
79.4 \% \\
\end{array}$ & $\begin{array}{c}350 \\
0 \\
500 \\
700 \\
50 \\
100 \\
50 \\
50 \\
1000 \\
150 \\
1000 \\
250 \\
500 \\
86.9 \% \\
\end{array}$ & $\begin{array}{r}0 \\
50 \\
3000 \\
100 \\
250 \\
100 \\
150 \\
88.7 \%\end{array}$ & $\begin{array}{r}0 \\
50 \\
7000 \\
0 \\
300 \\
200 \\
150 \\
76.2 \% \\
\end{array}$ & $\begin{array}{r}10000 \\
0 \\
150 \\
50 \\
100 \\
43.2 \% \\
\end{array}$ & $\begin{array}{r}350 \\
0 \\
50 \\
98.1 \% \\
\end{array}$ \\
\hline
\end{tabular}

* Fasted 24 hours and treated with 3 ounces of a $11 / 2 \%$ solution of copper sulphate at intervals of 21 days.

TABLE 6-Summary of the results of the treatment of sheep in Lots $I$ and II Lot 1

Starved 24 hours before treatment; treated at intervals of 21 days with 3 ounces of a $1 \%$ solution of copper sulphate

\begin{tabular}{|c|c|c|c|c|c|}
\hline $\begin{array}{c}\text { Number of } \\
\text { sheep } \\
\text { treated }\end{array}$ & $\begin{array}{c}\text { Number of } \\
\text { times } \\
\text { treated }\end{array}$ & $\begin{array}{c}\% \text { reduction } \\
\text { of nematode } \\
\text { ova }\end{array}$ & $\begin{array}{c}\text { Number of } \\
\text { sheep } \\
\text { treated }\end{array}$ & $\begin{array}{c}\text { Number of } \\
\text { times } \\
\text { treated }\end{array}$ & $\begin{array}{c}\begin{array}{c}\% \text { reduction } \\
\text { of nematode } \\
\text { ova }\end{array} \\
\end{array}$ \\
\hline $\begin{array}{r}15 \\
11 \\
10 \\
5 \\
3 \\
1\end{array}$ & $\begin{array}{r}3 \\
6 \\
8 \\
11 \\
12 \\
13\end{array}$ & $\begin{array}{l}50.0 \\
81.2 \\
55.8 \\
21.7 \\
55.0 \\
88.0\end{array}$ & $\begin{array}{r}15 \\
13 \\
13 \\
7 \\
7 \\
5 \\
3\end{array}$ & $\begin{array}{r}3 \\
6 \\
8 \\
11 \\
12 \\
13 \\
16\end{array}$ & $\begin{array}{l}35.1 \\
79.4 \\
86.9 \\
88.7 \\
76.2 \\
43.2 \\
98.1\end{array}$ \\
\hline
\end{tabular}

A comparison of the total ova count in the feces of the sheep before treatment and after the last treatment just preceding autopsy shows a reduction of 68.8 percent in nematode ova during the period of treatment.

If one sheep, No. 52 (see also Table 4), is eliminated from the experiment, the reduction in ova will be 91.7 percent. This animal, like No. 63 in Lot I, failed to respond to treatment and showed a marked increase in ova in the feces during the period of treatment. 


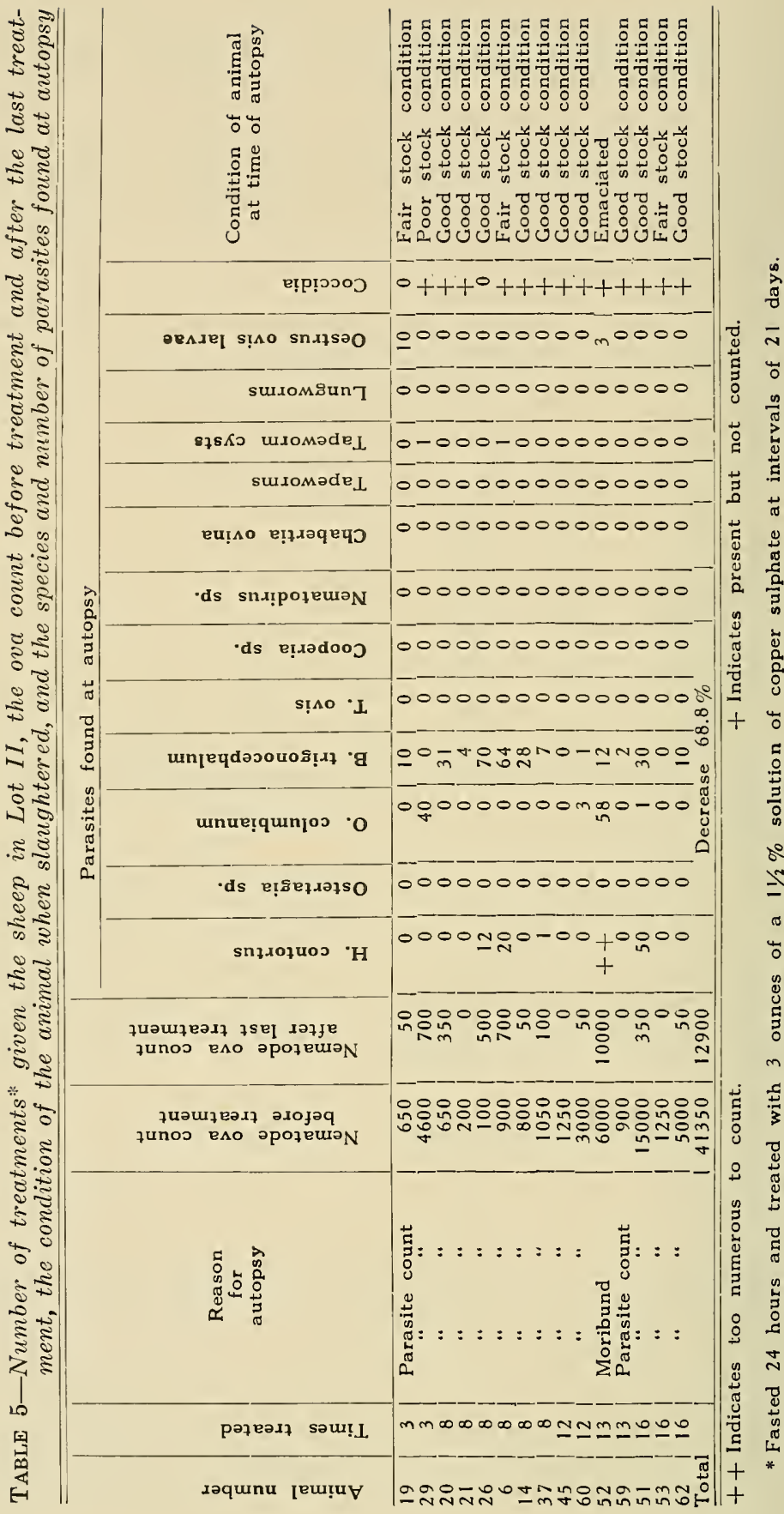


Tables 6 and 7 respectively show a summary of the results of the treatments of Lots I and II, and of the same lots with one sheep each, No. 63 of Lot I and No. 52 of Lot II, eliminated from the experiment. These two sheep did not respond to treatment and are responsible for the apparently inconsistent results shown in Table 6.

\section{EXPERIMENTS WITH FLOCK B}

\section{Manner of treating and handling}

Twenty-two sheep that showed symptoms of advanced parasitism were numbered for identification, divided into two lots of eleven each, and designated as Lots III and IV. The sheep in both lots were treated at intervals of 21 days with $41 / 2$ ounces of a 1 percent solution of copper sulphate. Those in Lot III were starved 24 hours before treatment, while those in Lot IV were not starved.

Twenty-seven sheep exhibiting symptoms of advanced parasitism were numbered for identification, and divided into two lots designated as Lots V and VI. The sheep in both lots were treated at intervals of 21 days with 3 ounces of a $11 / 2$ percent solution of copper sulphate. Sixteen sheep in Lot V were starved 24 hours before treatment, while the eleven sheep in Lot VI were not starved. Pasturing, feeding, and handling was the same as in Flock A.

TABLE 7-Summary of the results of the treatment of sheep in Lots $I$ and $I I$, with sheep No. 63 of Lot I and sheep No. 52 of Lot II eliminated

\begin{tabular}{|c|c|c|c|c|c|c|}
\hline \multicolumn{3}{|c|}{ Lot I } & \multicolumn{4}{|c|}{ Lot 11} \\
\hline \multicolumn{3}{|c|}{$\begin{array}{l}\text { Starved } 24 \text { hours before treatment; treated } \\
\text { at intervals of } 21 \text { days with } 3 \text { ounces of } \\
\text { a } 1 \% \text { solution of copper sulphate }\end{array}$} & \multicolumn{4}{|c|}{$\begin{array}{l}\text { Starved } 24 \text { hours before treatment; treated } \\
\text { at intervals of } 21 \text { days with } 3 \text { ounces of } \\
\text { a } 11 / 2 \% \text { solution of copper sulphate }\end{array}$} \\
\hline $\begin{array}{c}\text { Number of } \\
\text { sheep } \\
\text { treated }\end{array}$ & $\begin{array}{c}\text { Number of } \\
\text { times } \\
\text { treated }\end{array}$ & $\begin{array}{c}\begin{array}{c}\% \\
\text { reduction } \\
\text { of nematode } \\
\text { ova }\end{array} \\
\end{array}$ & $\begin{array}{c}\text { Number of } \\
\text { times } \\
\text { treated }\end{array}$ & $\begin{array}{l}\text { Number of } \\
\text { sheep } \\
\text { treated }\end{array}$ & $\begin{array}{l}\% \\
\text { of }\end{array}$ & $\begin{array}{l}\text { reduction } \\
\text { nematode } \\
\text { ova }\end{array}$ \\
\hline $\begin{array}{r}14 \\
10 \\
9 \\
4 \\
3 \\
1\end{array}$ & $\begin{array}{r}3 \\
6 \\
8 \\
11 \\
12 \\
13\end{array}$ & $\begin{array}{r}49.5 \\
80.7 \\
80.0 \\
-\quad 80.7 \\
\therefore \quad 55.0 \\
88.0\end{array}$ & $\begin{array}{r}14 \\
12 \\
12 \\
6 \\
6 \\
4 \\
3\end{array}$ & $\begin{array}{r}3 \\
6 \\
8 \\
11 \\
11 \\
13 \\
16\end{array}$ & & $\begin{array}{l}44.1 \\
83.1 \\
87.0 \\
96.6 \\
96.5 \\
98.9 \\
98.1\end{array}$ \\
\hline
\end{tabular}

The sheep in Lots III, IV, V, and VI together with five untreated controls were pastured and fed together as one flock unit, $B$, from June, 1932, until autopsy or the termination of the experiment in August, 1933.

Results of treatment

Tables 8 and 9 show the count of nematode ova in the feces of the sheep in Lot.III before treatment was begun and after the third, sixth, eleventh, thirteenth, seventeenth, and twenty-first treatments. There are shown also the condition of the sheep and the number of each species of parasite found at autopsy.

A comparison of the total ova count in the feces of the sheep before treatment and after the last treatment shows a reduction of 50.8 percent in nematode ova during the period of treatment. 


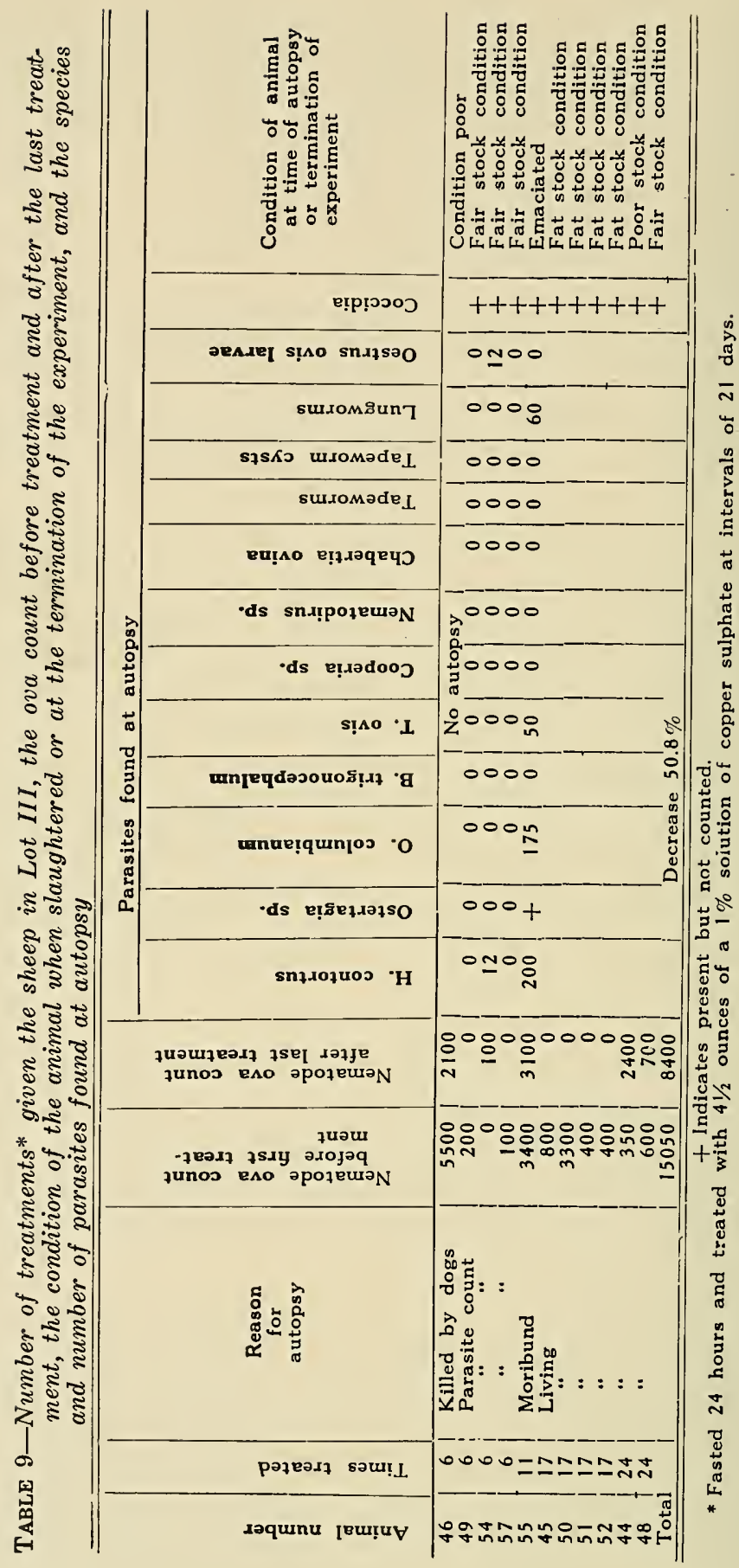


Tables 10 and 11 show the count of nematode ova in the feces of the sheep in Lot IV before the treatment was begun and following the third, fourth, sixth, eighth, eleventh, thirteenth, seventeenth, and twenty-first treatments. Lot IV consisted of twelve

TABLE 8-Nematode ova count in the feces of sheep in Lot III before treatment and following the treatment* indicated

\begin{tabular}{|c|c|c|c|c|c|c|c|c|}
\hline \multicolumn{9}{|c|}{ Number of treatments } \\
\hline $\begin{array}{l}\text { Animal } \\
\text { number }\end{array}$ & 0 & 3 & 6 & 8 & 11 & 13 & 17 & 21 \\
\hline $\begin{array}{l}46 \\
49 \\
54 \\
57 \\
55 \\
45 \\
50 \\
51 \\
52 \\
44 \\
48 \\
\text { Increase }\end{array}$ & $\begin{array}{c}5500 \\
200 \\
0 \\
100 \\
3400 \\
800 \\
3300 \\
400 \\
400 \\
350 \\
600 \\
\text { decrease }\end{array}$ & $\begin{array}{r}1900 \\
100 \\
0 \\
100 \\
3000 \\
300 \\
2000 \\
-700 \\
400 \\
600 \\
-40.8\end{array}$ & $\begin{array}{r}2100 \\
0 \\
100 \\
0 \\
3600 \\
600 \\
1300 \\
400 \\
1400 \\
600 \\
1100 \\
-25.5\end{array}$ & $\begin{array}{r}6300 \\
1700 \\
600 \\
400 \\
2600 \\
200 \\
800 \\
+36.2\end{array}$ & $\begin{array}{r}3100 \\
800 \\
400 \\
900 \\
0 \\
1800 \\
200 \\
-22.1\end{array}$ & $\begin{array}{r}300 \\
0 \\
400 \\
J \\
1500 \\
200 \\
-58.9\end{array}$ & $\begin{array}{r}0 \\
0 \\
0 \\
0 \\
2100 \\
-60.0\end{array}$ & $\begin{array}{r}2100 \\
600 \\
+184 .\end{array}$ \\
\hline
\end{tabular}

* Fasted 24 hours and treated with $41 / 2$ ounces of a $1 \%$ solution of copper sulphate at intervals of 21 days.

TABLE 10-Nematode ova count in the feces of sheep in Lot IV before treatment and following the treatment* indicated

\begin{tabular}{|c|c|c|c|c|c|c|c|c|c|}
\hline \multicolumn{10}{|c|}{ Number of treatments } \\
\hline $\begin{array}{l}\text { Animal } \\
\text { number }\end{array}$ & 0 & 3 & 4 & 6 & 8 & 11 & 13 & 17 & 21 \\
\hline $\begin{array}{l}32 \\
1 \\
2 \\
3 \\
4 \\
5 \\
6 \\
7 \\
26 \\
27 \\
30 \\
31 \\
22 \\
23 \\
24 \\
21 \\
\text { Increase } \\
\text { decrease }\end{array}$ & $\begin{array}{r}1500 \\
100 \\
1100 \\
300 \\
0 \\
100 \\
0 \\
100 \\
300 \\
1100 \\
300 \\
1000 \\
3500 \\
400 \\
250 \\
50 \\
\text { or } \quad\end{array}$ & $\begin{array}{r}200 \\
300 \\
700 \\
100 \\
0 \\
300 \\
0 \\
0 \\
200 \\
500 \\
500 \\
200 \\
3600 \\
300 \\
0 \\
0 \\
-31.6 \%\end{array}$ & $\begin{array}{r}- \\
0 \\
0 \\
0 \\
0 \\
0 \\
0 \\
0 \\
0 \\
100 \\
0 \\
200 \\
- \\
- \\
- \\
-94.9 \%\end{array}$ & 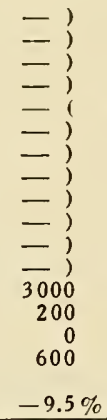 & $\begin{array}{r}4500 \\
400 \\
200 \\
1000 \\
+45.2 \%\end{array}$ & $\begin{array}{r}2300 \\
200 \\
0 \\
400 \\
-30.9 \% \\
\end{array}$ & $\begin{array}{r}2300 \\
100 \\
0 \\
600 \\
-28.5 \% \\
\end{array}$ & $\begin{array}{r}1100 \\
0 \\
0 \\
100 \\
-72.1 \%\end{array}$ & $\begin{array}{r}\bar{Z} \\
3 \overline{00} \\
+500 \%\end{array}$ \\
\hline
\end{tabular}

* Treated with $41 / 2$ ounces of a $1 \%$ solution of copper sulphate at intervals of 31 days; not starved before treatment.

lambs and four adult sheep. The 12 lambs had been treated with a 1 percent solution of copper sulphate since an age of about 5 weeks, the dosage being increased gradually from one ounce at 5 weeks to $41 / 2$ ounces at 10 weeks. These lambs received only four treatments of $41 / 2$ ounces each.

The nematode ova count in the feces of the 12 lambs was reduced 91.3 percent during the period covered by the four treatments. The four adult sheep treated seventeen to 21 times showed a decrease of 66.6 percent in nematode ova during the period of treatment. The condition of the sheep and the number of each species of parasite found at autopsy also are shown. 


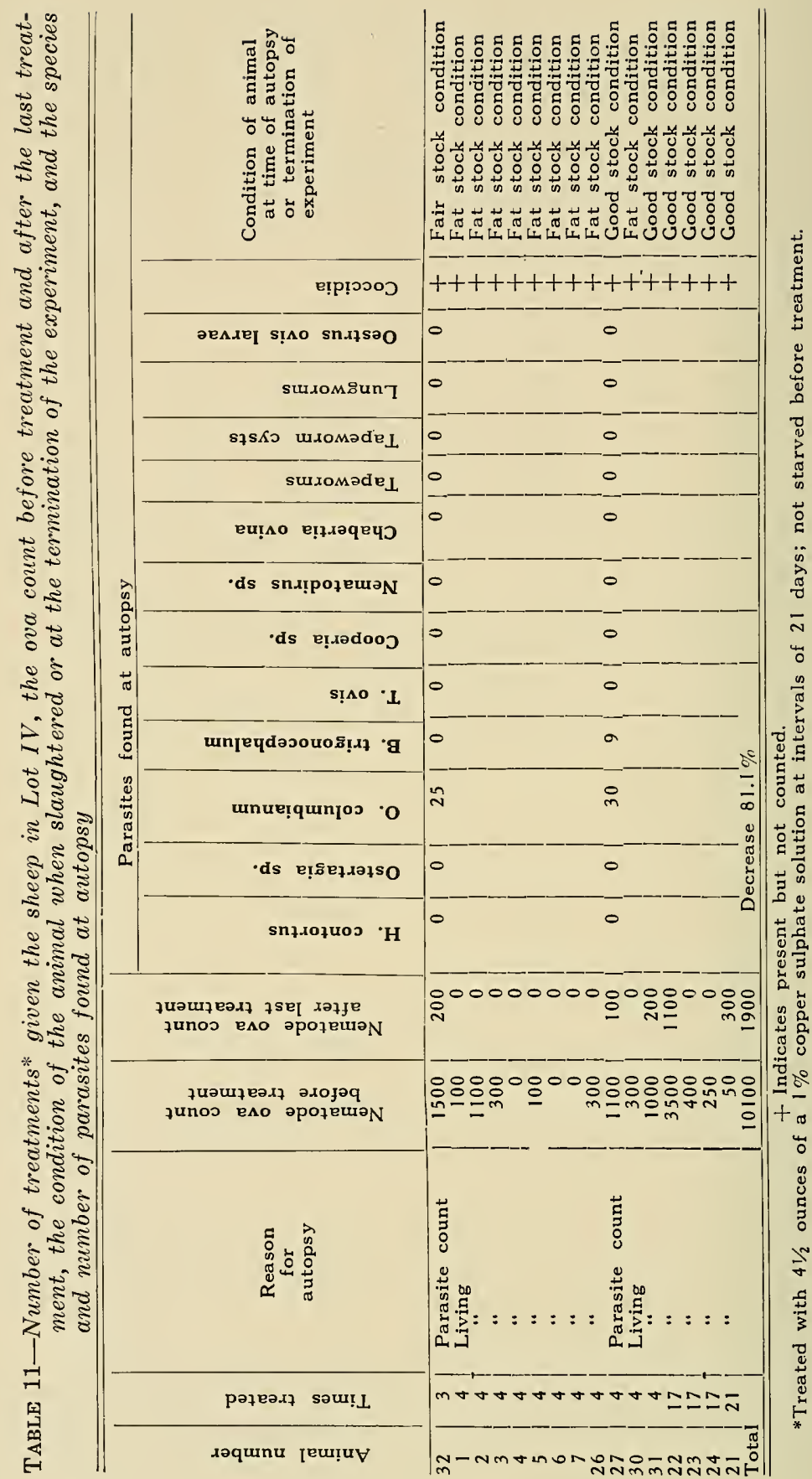


A comparison of the total ova count in the feces of the sheep before treatment and after the last treatment shows a reduction of 81.1 percent in nematode ova during the period of treatment.

TABLE 12-Nematode ova count in the feces of sheep in Lot $V$ before treatment and following the treatment* indicated

\begin{tabular}{|c|c|c|c|c|c|c|c|c|}
\hline \multicolumn{9}{|c|}{ Number of treatments } \\
\hline $\begin{array}{l}\text { Animal } \\
\text { number }\end{array}$ & 0 & 3 & 6 & 8 & 11 & 13 & 17 & 21 \\
\hline $\begin{array}{l}36 \\
37 \\
38 \\
39 \\
40 \\
42 \\
43 \\
71 \\
96 \\
70 \\
97 \\
100 \\
41 \\
33 \\
34 \\
35 \\
\text { Decrease } \\
\end{array}$ & $\begin{array}{r}0 \\
5300 \\
200 \\
400 \\
200 \\
100 \\
100 \\
23500 \\
200 \\
2100 \\
16000 \\
16400 \\
0 \\
900 \\
100 \\
800\end{array}$ & $\begin{array}{r}0 \\
600 \\
0 \\
400 \\
0 \\
100 \\
4800 \\
400 \\
500 \\
6200 \\
5700 \\
100 \\
0 \\
71.6 \% \\
\end{array}$ & $\begin{array}{r}100 \\
0 \\
0 \\
200 \\
100 \\
0 \\
0 \\
300 \\
300 \\
200 \\
1500 \\
1300 \\
400 \\
100 \\
0 \\
0 \\
93.2 \% \\
\end{array}$ & $\begin{array}{r}200 \\
200 \\
100 \\
3200 \\
2300 \\
200 \\
300 \\
0 \\
0 \\
89.1 \% \\
\end{array}$ & $\begin{array}{r}500 \\
500 \\
100 \\
300 \\
0 \\
0 \\
0 \\
96.1 \% \\
\end{array}$ & $\begin{array}{r}0 \\
0 \\
0 \\
100 \% \\
\end{array}$ & $\begin{array}{r}0 \\
0 \\
0 \\
100 \% \\
\end{array}$ & $\begin{array}{r}0 \\
0 \\
0 \\
100 \% \\
\end{array}$ \\
\hline
\end{tabular}

* Fasted 24 hours and treated with 3 ounces of a $11 / 2 \%$ solution of copper sulphate at intervals of 21 days.

TABLE 14-Nematode ova count in the feces of sheep in Lot VI before treatment and following the treatment* indicated

\begin{tabular}{|c|c|c|c|c|c|c|c|c|}
\hline \multicolumn{9}{|c|}{ Number of treatments } \\
\hline $\begin{array}{l}\text { Animal } \\
\text { number }\end{array}$ & 0 & 3 & 6 & 8 & 11 & 13 & 17 & 21 \\
\hline $\begin{array}{r}12 \\
9 \\
17 \\
19 \\
13 \\
10 \\
11 \\
14 \\
16 \\
18 \\
20 \\
\text { Decrease }\end{array}$ & $\begin{array}{r}600 \\
9000 \\
100 \\
50 \\
1100 \\
200 \\
1800 \\
50 \\
200 \\
150 \\
6100\end{array}$ & $\begin{array}{r}1000 \\
6000 \\
100 \\
0 \\
900 \\
200 \\
1300 \\
0 \\
300 \\
400 \\
2200 \\
35.9 \%\end{array}$ & $\begin{array}{r}600 \\
0 \\
0 \\
3000 \\
700 \\
1000 \\
100 \\
1400 \\
400 \\
1100 \\
54.0 \%\end{array}$ & $\begin{array}{r}0 \\
3100 \\
700 \\
1300 \\
100 \\
600 \\
0 \\
300 \\
30.5 \%\end{array}$ & $\begin{array}{r}0 \\
1200 \\
100 \\
400 \\
400 \\
400 \\
0 \\
400 \\
69.9 \%\end{array}$ & $\begin{array}{r}300 \\
0 \\
0 \\
200 \\
0 \\
800 \\
84.7 \%\end{array}$ & E & $\begin{array}{r}200 \\
100 \\
200 \\
100 \\
700 \\
500 \\
78.9 \%\end{array}$ \\
\hline
\end{tabular}

* Treated with 3 ounces of a $1 \frac{1}{2} \%$ solution of copper sulphate at intervals of 21 days; not fasted before treatment.

Tables 12 and 13 show the count of nematode ova in the feces of the sheep in Lot $\mathrm{V}$ before treatment was begun and following the third, sixth, eleventh, thirteenth, seventeenth, and twenty-first treatment. There is shown also the condition of the sheep and the number of each species of parasite found at autopsy.

A comparison of the total cva count in the feces of the sheep before treatment and after the last treatment shows a reduction of 96.6 percent in nematode ova during the period of treatment. 


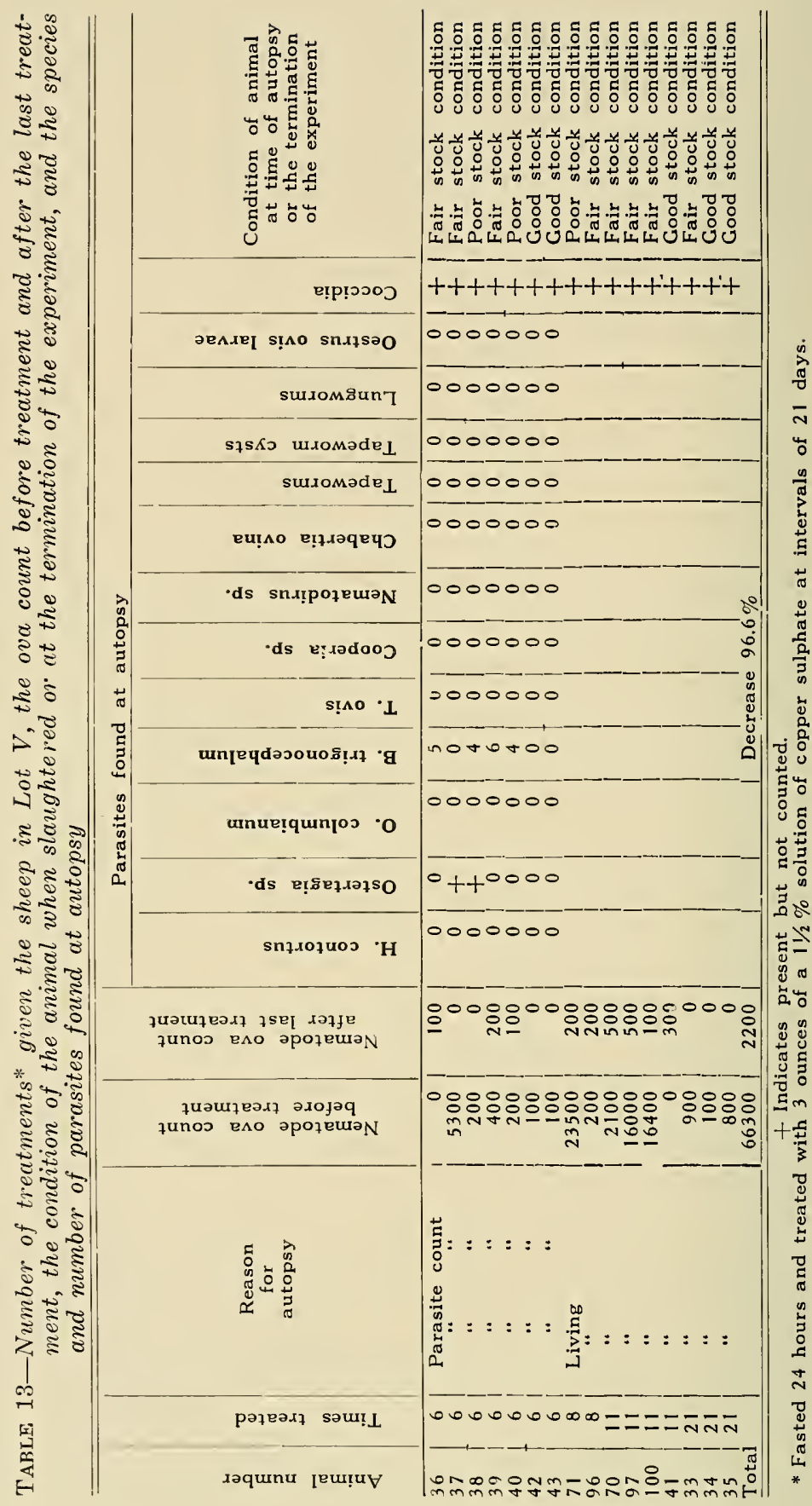




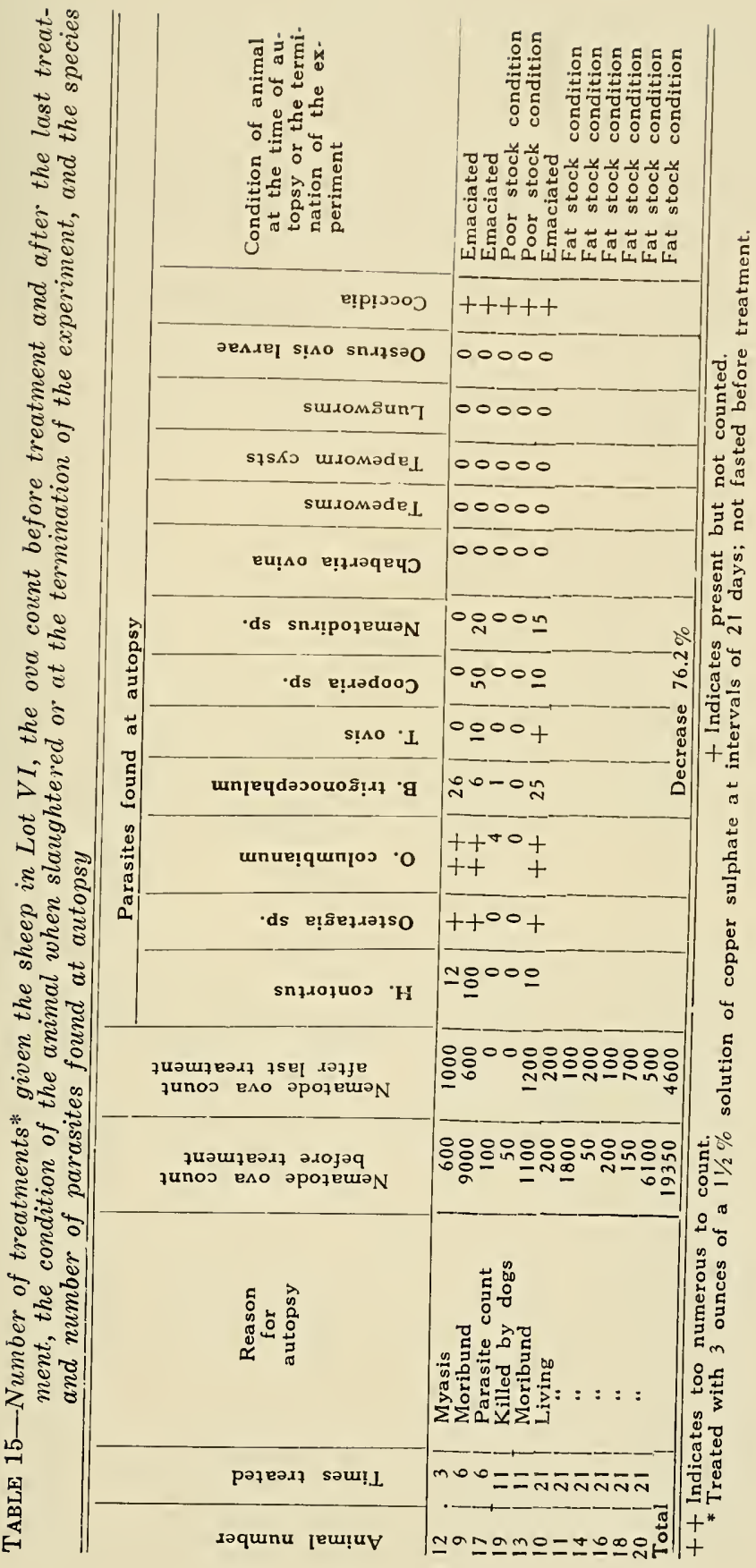


Tables 14 and 15 show the count of nematode ova in the feces of the sheep in Lot VI, before treatment was begun and after the third, sixth, eleventh, thirteenth, and twenty-first treatment. There is also shown the condition of the sheep and the number of each species of parasite found at autopsy.

A comparison of the total ova count in the feces of the sheep before treatment and after the last treatment shows a reduction of 76.2 percent in nematode ova, during the period of treatment.

\section{TABLE 16-Summary of results of treatment of sheep in Lots III and IV}

\begin{tabular}{|c|c|c|c|c|c|c|c|}
\hline \multicolumn{4}{|c|}{$\begin{array}{l}\text { Lot } 111 \text { treated with } 41 / 2 \text { ounces of a } 1 \% \\
\text { copper sulphate solution; starved } 24 \\
\text { hours before treatment } \\
\end{array}$} & \multicolumn{4}{|c|}{$\begin{array}{l}\text { Lot IV treated with } 41 / 2 \text { ounces of a } 1 \% \\
\text { copper sulphate solution; not starved } \\
\text { before treatment }\end{array}$} \\
\hline $\begin{array}{l}\text { Number of } \\
\text { sheep } \\
\text { treated }\end{array}$ & $\begin{array}{l}\text { Number of } \\
\text { times } \\
\text { treated }\end{array}$ & $\begin{array}{l}\% \\
\text { of }\end{array}$ & $\begin{array}{l}\text { reduction } \\
\text { nematode } \\
\text { ova }\end{array}$ & $\begin{array}{l}\text { Number of } \\
\text { sheep } \\
\text { treated }\end{array}$ & $\begin{array}{c}\text { Number of } \\
\text { times } \\
\text { treated }\end{array}$ & $\begin{array}{l}\% \\
\text { of }\end{array}$ & $\begin{array}{l}\text { reduction } \\
\text { nematode } \\
\text { ova }\end{array}$ \\
\hline $\begin{array}{r}11 \\
11 \\
7 \\
7 \\
6 \\
5 \\
2\end{array}$ & $\begin{array}{r}3 \\
6 \\
8 \\
11 \\
13 \\
17 \\
21\end{array}$ & & $\begin{array}{r}40.8 \\
25.5 \\
+36.2 \\
22.1 \\
58.9 \\
+60.0 \\
+184.0\end{array}$ & $\begin{array}{r}16 \\
4 \\
4 \\
4 \\
4 \\
4 \\
1\end{array}$ & $\begin{array}{r}3 \\
6 \\
8 \\
11 \\
13 \\
17 \\
21\end{array}$ & & $\begin{array}{r}31.6 \\
9.5 \\
+45.2 \\
30.9 \\
28.5 \\
72.1 \\
+500.0\end{array}$ \\
\hline
\end{tabular}

TABLE 17-Summary of results of treatment of sheep in Lots $V$ and VI

\begin{tabular}{|c|c|c|c|c|c|c|c|}
\hline \multicolumn{4}{|c|}{$\begin{array}{l}\text { Lot V treated with } 3 \text { ounces of a } 11 / 2 \% \\
\text { solution of copper sulphate; starved } 24 \\
\text { hours before treatment }\end{array}$} & \multicolumn{4}{|c|}{$\begin{array}{l}\text { Lot V1 treated with } 3 \text { ounces of a } 11 / 2 \% \\
\text { solution of copper sulphate; not starved } \\
\text { before treatment }\end{array}$} \\
\hline $\begin{array}{c}\text { Number of } \\
\text { sheep } \\
\text { treated }\end{array}$ & $\begin{array}{c}\text { Number of } \\
\text { times } \\
\text { treated }\end{array}$ & $\begin{array}{l}\% \\
\text { of }\end{array}$ & $\begin{array}{l}\text { reduction } \\
\text { nematode } \\
\text { ova }\end{array}$ & $\begin{array}{c}\text { Number of } \\
\text { sheep } \\
\text { treated }\end{array}$ & $\begin{array}{c}\text { Number of } \\
\text { times } \\
\text { treated }\end{array}$ & $\begin{array}{l}\% \\
\text { of }\end{array}$ & $\begin{array}{l}\text { reduction } \\
\text { nematode } \\
\text { ova }\end{array}$ \\
\hline $\begin{array}{r}16 \\
16 \\
9 \\
7 \\
4 \\
4 \\
4\end{array}$ & $\begin{array}{r}3 \\
6 \\
8 \\
11 \\
13 \\
17 \\
21\end{array}$ & & $\begin{array}{l}71.6 \\
93.2 \\
89.1 \\
96.1 \\
100 \\
100 \\
100\end{array}$ & $\begin{array}{r}11 \\
10 \\
8 \\
8 \\
6 \\
6 \\
6 \\
\end{array}$ & $\begin{array}{r}3 \\
6 \\
8 \\
11 \\
13 \\
17 \\
21 \\
\end{array}$ & & $\begin{array}{l}35.9 \\
54.0 \\
30.5 \\
69.9 \\
84.7 \\
\text { lot taken } \\
78.9 \\
\end{array}$ \\
\hline
\end{tabular}

Table 16 shows a comparison of the results of treatment in the increase or decrease of nematode ova in the feces of sheep in Lot III, which were starved-before treatment, and in Lot IV, which were not starved before treatment. Both lots were treated at intervals of 21 days, with $41 / 2$ ounces of a $1 \%$ solution of copper sulphate.

Table 17 compares the results of treatment in the increase or decrease of nematode ova in the feces of sheep in Lot $V$, starved before treatment, and Lot VI, not starved before treatment. Both lots were treated at intervals of 21 days with 3 ounces of a $11 / 2 \%$ solution of copper sulphate.

Table 18 shows the record of the untreated control sheep that were kept for varying periods of time in the pastures with the copper-sulphate treated sheep of Flocks A and B. The control sheep were chosen because they showed a low ova count in the feces or were in better condition than the sheep selected for treatment. If we compare the total count of ova in the feces of the 
controls at the beginning of the experiment with the ova count just preceding autopsy, it will be found that there was an increase of $1240 \%$ in nematode ova during the period of time they were in the Flocks A and B. There are shown also the condition of the sheep at the time of autopsy and the number of each species of nematode found at autopsy.

Control animal No. 43 was killed by dogs just 12 weeks after being placed in the flock. Animal No. 47 was in the flock 44 weeks. These animals were the extremes in period of time the controls lived in the flocks.

\section{SUMMARY}

In Table 19 is shown the average percentage of efficiency in reducing nematode ova in the feces of the sheep in Flocks A (Lots I and II) and $\mathrm{B}$ (Lots III, IV, V, and VI).

Fourteen sheep that had been prepared for treatment by starving 24 hours were given an average of 8.15 treatments, with 3 ounces of a 1 percent solution of copper sulphate. This resulted in a 71.7 percent reduction in nematode ova during the period of treatment. One sheep, No. 63, was omitted from these calculations because the animal did not respond to treatment and is not representative of the action of copper sulphate as an anthelmintic.

Eleven sheep that had been prepared for treatment by starving 24 hour's were given an average of 14 treatments, with $41 / 2$ ounces each of a 1 percent solution of copper sulphate. There was a reduction of 50.8 percent in nematode ova in this group during the period of treatment.

Four sheep, adults that were not starved before treatment, received an average of 18 treatments of $41 / 2$ ounces each of a 1 percent solution of copper sulphate. There was a reduction of 66.6 percent in the nematode ova in this group during the period of treatment.

Twelve sheep, yearlings that were not starved before treatment, were given four treatments of $41 / 2$ ounces each of a 1 percent solution of copper sulphate. A reduction was noted of 91.3 percent in the nematode ova in this group during the period of treatment.

Sixteen sheep, adults and yearlings, not starved before treatment, were given an average of 7.45 treatments of $41 / 2$ ounces each of a 1 percent solution of copper sulphate. There was a reduction of 81.1 percent in nematode ova in this group during the period of treatment.

Eleven sheep that were not starved before treatment were given an average of 14.8 treatments of 3 ounces of a $11 / 2$ percent solution of copper sulphate. There was a reduction of 76.0 percent in nematode ova in this group during the period of treatment. 


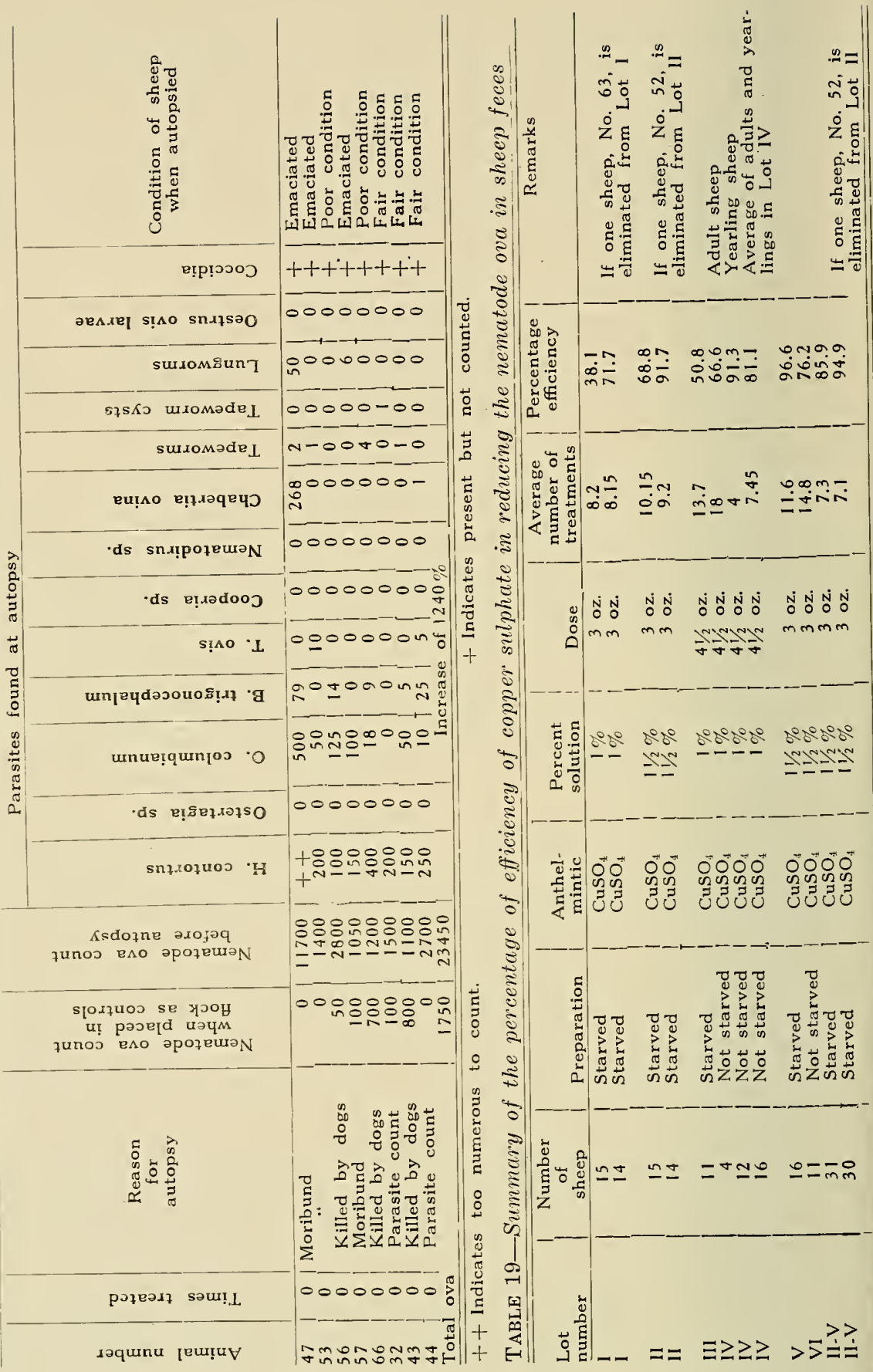


Thirty sheep that had been prepared for treatment by starving 24 hours were given an average of 7.1 treatments of 3 ounces each of a $11 / 2$ percent solution of copper sulphate. There was a reduction of 94.9 percent in nematode ova in this group during the period of treatment. One sheep, No. 52, was omitted from these calculations because this animal did not respond to treatment and is not representative of the action of copper sulphate as an anthelmintic.

\section{THE EFFECT OF COPPER SULPHATE UPON INTESTINAL} PARASITES OF SHEEP

\section{Cestodes (Tapeworms)}

Only 47 of the sheep treated with copper sulphate were autopsied. Three sheep of this group showed one small immature tapeworm each. These three sheep belonged to the group treated with the 1 percent solution. Of the eight untreated control sheep, four showed tapeworms at autopsy. There were seven large mature parasites and one small immature one.

\section{Bunostomum trigonocephalum (Hookworm)}

Hookworms were found at autopsy in 62.5 percent of the untreated control animals and in 68.1 percent of the treated animals. The average number of parasites per host for the untreated control group was 16.5, and for the treated group, 12.7 .

\section{Oesophagostomum columbianum (Nodularworm)}

Nodular worms were found at autopsy in 87.5 percent of the untreated control animals and in 40.4 percent of the treated animals. The parasites in three of the treated sheep were not counted but were estimated at about 500 each. The average number of parasites per host for the untreated control group was 102.8, and for the treated group, 46.8 .

\section{Trichuris ovis (Whipworms)}

Whipworms were found only in two of the control animals and in three of the treated animals. Consequently in view of the small number of animals involved no comparison is made.

\section{OTHER ANTHELMINTICS}

During the progress of this series of treatments a few sheep were treated with (1) 3 ounces of $11 / 2$ percent nicotine sulphate; (2) 3 ounces of a mixture of equal parts $1 \frac{1}{2}$ percent nicotine sulphate and $11 / 2$ percent copper sulphate solution; (3) 5 c.c. of tetrachlorethylene; (4) 20 c.c. of colloidal iodine (Merck); and (5) calcium polysulphite. These sheep were pastured and fed with the flocks that were treated with the copper sulphate solution.

The results of autopsy and the count of the ova in the feces indicate that none of these preprations is superior in effectiveness to the $11 / 2$ percent solution of copper sulphate, and some of them were less effective in eliminating gastro-intestinal parasites from sheep. 
Calcium polysulphite was used as the anthelmintic in a considerable number of sheep. The dosage was varied from 1 ounce to 12 ounces of a 1 percent solution to a 1 ounce to $2 \frac{1}{2}$ ounces of a 12 percent solution. A 6 -ounce dose of a $11 / 2 \%$ solution was found effective in causing a reduction in the nematode ova in the feces, but calcium polysulphite in all dilutions used caused nausea in many of the sheep. Dilutions as low as $11 / 2$ percent were irritating to the mucous membrane of both the stomach and intestines, and the sheep failed to regain flesh properly. Dilutions of $21 / 2$ percent or more were toxic under certain conditions and caused the death of a few of the sheep.

\section{EFFECT OF STARVING UPON THE PROPER DELIVERY OF THE ANTHELMINTIC TO THE ABOMASUM}

Sixteen sheep in this experiment were drenched with 3 ounces of dye solution (Rhodamin B) just before slaughter. These sheep were not starved before drenching. The autopsies showed that all the dye had passed to the abomasum in only five sheep. In five sheep the entire dose of dye entered the rumen. In five sheep the solution was found in the rumen and reticulum. In one sheep it was found in the rumen, reticulum, and omasum.

Six sheep in this experiment were starved 24 hours and drenched with 3 ounces of the dye solution just before slaughter. The autopsies showed that all the solution had passed to the abomasum in two sheep. The larger part had passed to the abomasum in the other four sheep, but a trace of red was present in the rumen in one sheep, rumen and reticulum in one sheep, reticulum and omasum in one sheep, and omasum in one sheep.

If the results of these few trials can be accepted as indicative, it may explain why certain individuals fail wholly or partially to respond to treatment. In those sheep that give only partial or no response, probably the drench solution passed in part or in its entirety to the rumen or compartment other than the abomasum.

\section{DISCUSSION}

If we study and compare the results of treatment of sheep in Lot I, as shown in Tables 2 and 3 , and Lot II, as shown in Tables 4 and 5 , it will be found that four sheep in Lot I were free from Hoemonchus contortus (stomach worms) and four sheep retained a considerable number of these parasites. The remaining seven sheep each showed a few of these parasites. There was an average of 38.1 percent reduction in nematode ova in the feces of the sheep in Lot I at the time of autopsy.

Lot II shows ten sheep free from Hoemonchus contortus and one sheep retaining a considerable number of these parasites. The remaining four sheep each showed a few of these parasites. There 
was an average of 68.8 percent reduction of the nematode ova in the feces of the sheep in Lot II at the time of autopsy.

One sheep in each lot showed a marked increase in the nematode ova in the feces at the last fecal examination before autopsy. These two sheep caused the low efficiency of the copper-sulphate solution in each lot. (See Tables 6 and 7 ).

The general condition of the two lots was practically alike at the beginning of treatment. If any difference existed. Lot I may have been in slightly better condition than Lot II.

At the time of autopsy Lot I showed five sheep in good condition, fre sheep in fair condition, three sheep in poor condition, and two emaciated sheep. Lot II showed ten sheep in good condition, three sheep in fair condition. one sheep in poor condition, and one emaciated sheep.

If we compare the results of treatment of the sheep in Lot III, as shown in Tables 8 and 9 , and Lot IV as shown in Tables 10 and 11, it will be found that only four sheep in Lot III have been autopsied. Two sheep were found free of Hoemonchus contortus and one retained a considerable number and one a few of these parasites. There was an arerage of 50.8 percent reduction in the nematode ova in the feces of the sheep in Lot III at the time of autopsy or the termination of the experiment.

Lot IV consisted of 12 lambs and four adult sheep. Treatment of the lambs was begun at fire to six weeks of age and continued at intervals of 21 days, with gradually increasing dosage, until about ten months of age, when they were receiving the adult dose of $41 \%$ ounces. These 12 lambs (yearlings) rere transferred to another experiment when about 13 months of age. having been given only four treatments of $4^{1} \underline{\underline{2}}$ ounces each.

The 12 yearlings show an arerage reduction of 91.3 percent in the nematode ora in their feces. while the four adults show only 66.6 percent reduction.

At the time of autopsy or termination of the experiment Lot III showed four sheep in fat condition, four in fair condition, two in poor condition, and one emaciated. Lot IV showed nine sheep in fat condition. six in good condition, and one in fair condition.

If we compare the results of treatment of the sheep in Lot $V$. as shown in Tables 12 and 13, and Lot VI, as shown in Tables 14 and 15. it will be found that seren sheep in Lot $V$ hare been autopsied and all seven were free from Hoemonchus contortus. There was an average reduction of 96.6 percent in nematode ora in the feces of the sheep in Lot $F$ at the time of autopsy or termination of the experiment.

Only five sheep were autopsied from Lot VI. Two of these sheep were found free of Hoemonchus contortus and one retained a considerable number and two a few parasites. 
There was an average reduction of 76.2 percent in nematode ova in the feces of the sheep in Lot VI at the time of autopsy or the termination of the experiment. At this time the sheep in Lot V showed five sheep in good condition, eight in fair condition, and three in poor condition. Lot VI showed six sheep in fat condition, two in poor condition, and three emaciated.

A careful analysis of Tables 8, 9, 12, and 13 indicates that there was little or no decrease in nematode ova in the feces of many of the sheep and an actual increase in some of the sheep for a period centering about the time of the eighth treatment of the sheep in Flock B. During a period before and after this time the pasture was exhausted and the quality of the hay was poor. A decrease in the ova count resulted soon after the resumption of feeding of good hay, which in this case was alfalfa.

This increase in nematode ova is also shown in the average figures in Tables 16 and 17.

The ova count in the feces throughout this examination apparently was influenced adversely by the reduction in the quality of the feed.

\section{CONCLUSIONS}

Withholding all food for a period of 24 hours before drenching ment increased the efficiency of the anthelmintic in the sheep used in these trials.

Withholding all food for a period of 24 hours before drenching sheep apparently influenced the passage of the drench solution to the abomasum.

A $11 / 2$ percent solution of copper sulphate was the most effective anthelmintic used against stomach worms in the sheep reported in these treatments.

A $11 / 2$ percent solution of copper sulphate was effective in removing tapeworms from the intestines of the sheep used in these trials, when regularly and systematically administered.

Regular and systematic treatment of sheep at intervals of 21 days with a $11 / 2$ percent solution of copper sulphate reduced the intestinal nematode infestation in the sheep used in these trials.

No ill effect was noted from the use of a $11 / 2$ percent solution of copper sulphate as used in these trials.

Feeding of good food in proper quantities is an essential factor in the successful use of anthelmintics (copper sulphate) in the elimination of gastro-intestinal parasites from sheep.

\section{REFERENCE}

(1) Stoll, N. R.

1923. InVESTIgations on the Control of Hookworm Disease: XV. AN EFFECTIVE METhod of Counting HookwORM EgGS IN FECES. Am. Jour. Hyg. 3: 59-70. 

